\title{
6. Stalin and the Death of Epic: Mikhail Bakhtin, Nadezhda Mandelstam, Boris PASTERNAK
}

Does epic belong to princes? Imperialists have often assumed that it does: Alexander of Macedonia, after pausing at Troy to envy Achilles for having found a Homer, swept on to India with an Iliad in a jewelled casket. Caesar Augustus extracted the Aeneid from an apparently reluctant poet of shorter forms. Napoleon took a copy of Ossian on his march to Moscow. And Mussolini's favorite play was Shakespeare's Julius Caesar, which, speaking better than he knew, he proclaimed to be a textbook for statesmen. Ezra Pound seconded the impulse, while trying to educate the taste.

Among general readers, few might dispute the association. The unfading image of Hitler at Bayreuth indicts the influence of all heroic art. Even with the battlefield replaced by the dynamo and the collective farm, what is bad about Stalin's socialist realism, like his architecture, is heroically bad. Poets of the first rank are not easily tarred by this brush. When epic poetry has gratified the naked bellicosity of the Alexanders and Napoleons, it has usually done so late and mistakenly, for Homer's most esteemed heirs have more often satirized than gratified regal claims to grandeur. Alexander presumably overlooked how Homer actually portrays the leaders of expeditions through the ineffectual, blustering, and ingloriously doomed Agamemnon. However much Virgil fostered Augustus' vanity in seeing himself as the new Aeneas, the poet also sees Turnus' self-presentation as the new Achilles as a mask for weakness. Dante lets the old heroism sink into the pit on the weight of its own presumptions, as we see in the unbending, unlearning Farinata; in a Ulysses eternally trapped in the tales of Ulysses; and in the great joke, Satan, throned in unyielding ice of his own creation.

Dante's case reminds us that the great national visions tend not to come from the political center of things, but depend instead on the distance and nostalgia of exile or expatriation (from Dante to Joyce to Walcott), lost partisan causes (Virgil and Milton), or, at the very least, getting out of town: Nikolai Gogol fled to Rome in 1836 to write Russia's great national book, 
which turned out to be Dead Souls. That lesson was not lost on the outcast intelligentsia of the Stalinist era. In his "Conversations about Dante," Osip Mandelstam, who always carried a compact Divine Comedy in case he should suddenly end up in prison, did not name the unmentionable Stalin in connection with Farinata and Ulysses but assumed the reference as damningly self-evident: "It is unthinkable to read the cantos of Dante without aiming them in the direction of the present day. They are made for that. They are missiles for capturing the future."1 Alexander Solzhenitsyn adapted Dante's image of self-cancelling heroics on the first page of The First Circle, where we first see the Soviet inferno through an eery light that cuts through the Moscow night: "...from ten oclock on, thousands of windows in sixty-five Moscow ministries would light up again. There was only one person behind a dozen fortress walls, who could not sleep at night, and he had taught all official Moscow to keep vigil with him until three or four in the morning." 2 In this infernal Moscow, the lucky ones are the imprisoned intellectuals out in the audio research center on the edge of the city, who, like Dante's worthy pagans in the first circle, occupy the comparatively pleasant rim of the pit. But at the center behind the dozen walls is the unmoved Mover, exiled from nature (for night brings no sleep), imprisoning others so as to lock himself the more firmly in the ice. Solzhenitsyn freely concedes all of the Great Insomniac's claims to be at the center of things, the dead center.

Heroic antiquity is one of the preferred ways of satirizing Stalin: Mandelstam styles him "the Assyrian." Pasternak allegorically uses the pockmarked Caligula for the pockmarked Stalin. ${ }^{3}$ Mikhail Bulgakov in The Master and Margarita interlards a tale of political cowardice in contemporary Moscow with the case of the Roman bureaucrat Pontius

${ }^{1}$ Osip Mandelstam, Osip Mandelstam: Selected Essays, trans. Sidney Monas (Austin and London: University of Texas Press, 1977), 24.

${ }^{2}$ Aleksandr I. Solzhenitsyn, The First Circle, trans. Thomas P. Whitney (New York: Harper and Row, 1968), 1.

${ }^{3}$ Masing-Delic argues that Pasternak uses Rome allegorically to trace the origins both of capitalism and socialism in their common use of wealth and spectacle, "bread and circuses," to suppress individuality. I. Masing-Delic, "Capitalist Bread and Socialist Spectacle: The Janus Face of 'Rome' in Pasternak's Doctor Zhivago," in Boris Pasternak and his Times: Selected Papers from the Second International Symposium on Pasternak, ed. Lazar Fleishman (Berkeley, Calif.: Brekeley Slavic Specialties, 1989). 
Pilate. The analogy to Rome is easily made for Moscow. The sixteenthcentury monk Philotheus called Moscow the third Rome, that is, a third and final capital of Christendom after Rome itself and Byzantium. With bitter irony Pasternak's sweeping historical narrative in Doctor Zhivago suggests that indeed Moscow has become a Rome, not the final capital of Christendom, but the Rome of Augustus and the Mediterranean empire. Rome is described as "a flea market of borrowed gods and conquered peoples" (Pasternak 1958, 43). ${ }^{4}$ As Zhivago's friend Misha Gordon reflects in the epilogue, "It has often happened in history that a lofty ideal has degenerated into crude materialism. Thus Greece gave way to Rome, and the Russian Enlightenment has become the Russian Revolution." The disappointed hopes of the revolution inspired Osip Mandelstam to speculate about a "Fourth Rome."

On this evidence, Boris Pasternak and Osip Mandelstam should figure among those who scorn heroic art, even that of antiquity, because of the atrocities of this century and who therefore turn away from Wagner and even Virgil as one would from German or Roman imperialism. Yet we shall argue that the oppressions of Stalinism deepened the classicism of both poets. Stalin once did, to be sure, serve as Muse for Mandelstam, when in the winter of 1936-37 he conceived the hope that a conciliatory gesture might save him or his wife. As Nadezhda Mandelstam recalls:

His attempt to do violence to himself was meeting stubborn resistance, and the artificially conceived poem about Stalin simply became a matrix for the utterly different material seething inside him - real poetry which was antagonistic to the "Ode" and canceled it out... A mention of Aeschylus and Prometheus in the "Ode" led on in the "free poems" to the theme of tragedy and martyrdom....?

In the fatal gap between a dictator waiting for Aeschylean encomium and a poet who turns to Promethean refusal, we can see the double life of heroic

${ }^{4}$ Boris Pasternak, Doctor Zhivago, prose trans. Max Hayward and Manya Harari, poems trans. Bernard Guerney (New York: Pantheon, 1958; repr. New York: Ballantine, 1981), 43. Page numbers for Doctor Zhivago are to the 1981 edition.

${ }^{5}$ Ibid, 518.

6 Nadezhda Mandelstam, Hope Against Hope, trans. Max Hayward (New York: Atheneum, 1970), 178. Mrs. Mandelstam's title is Vospominaniya, "Memoirs."

${ }^{7}$ lbid, 200. 
literature in our century. Although epic traditionally presents itself as the singing of praise, it may have survived into the modern era more as an act of resistance.

After his death, Stalin's negative inspiration showed itself in the publication of three important bodies of work that in quite various ways try to undo the reign of the lie by what we may call monumental "histories of voice": Boris Pasternak's Doctor Zhivago, the memoirs of Nadezhda Mandelstam, and the cultural theories of Mikhail Bakhtin. ${ }^{8}$ All three writers were born in the 1890s, shared the hopes of the 1917 revolution and the disillusionment of the 1920s, suffered silencing during the Stalinist era, and, in the case of Bakhtin and the Mandelstams, internal exile. From their various beginnings - as philologist, lyric poet, wife of a lyric poet - they were driven by oppression to prophecy on a grander scale than they might have imagined at the start of their careers. In their various ways, the three contend that the most fragile and evanescent of tones, be it lyrical or ironic, can survive and prevail in history and prove mightier than the organs of state terrorism. Some of the few who ever returned from the camps, as Mrs. Mandelstam notes, brought back snatches of her husband's verse.

Pasternak's semi-autobiographical Doctor Zhivago and the memoirs of Nadezhda Mandelstam tell similar tales of the silencing of a poet by the inhuman forces of the age. Both prose narratives aim to preserve and explain cycles of lyric poetry: the "Poems of Yurii Zhivago" printed at the end of the volume - implicitly the remains of Pasternak the lyric poet and the poems of Osip Mandelstam, still unpublished in Russia when his wife wrote in the 1960s. ${ }^{9}$ Both accounts invert materialist perspectives by making even the greatest historical events mere background to the lives of poets (the October Revolution happens between chapters in Doctor Zhivago), and those biographies in turn a footnote to the poems. The widows in these books tell similar tales. Lamenting over Yurii's corpse, Lara sums up his - and the novel's - view of history: “The riddle of life, the riddle of death, the enchantment of genius, the enchantment of unadorned

\footnotetext{
${ }^{8}$ We shall concentrate on "Epic and Novel" (1941) and "From the Prehistory of Novelistic Discourse" (1940) in Bakhtin (1981).

${ }^{9}$ The last collection of Mandelstam's verse to be published in the USSR was in 1928 under the title Stikhotvoreniya. Only after a forty-five year hiatus, in 1973, would a volume of his poetry appear in the USSR.
} 
beauty - yes, yes, these things were ours. But the small problems of practical life - things like the reshaping of the planet - these things, no thank you, they are not for us." ${ }^{10}$ Concerning the speculation of her husband's American editor that Mandelstam went to Armenia to avoid the Five Year Plans, Mrs. Mandelstam similarly expostulates: "Why should he have been put out by the planned organization of the economy? As if that mattered! What mattered was that, as M[andelstam] saw them, by virtue of their links between the Black Sea and the Mediterranean, the Crimea, Georgia and Armenia were part of world culture."11

Both Boris Pasternak and Nadezhda Mandelstam serve the fundamental need to provide witness once the terror has subsided. As a preface to her own memorial, Requiem, their friend and fellow sufferer Anna Akhmatova replaces the traditional visit of the Muse or scene of poetic vocation with a vignette from the prison queues of Leningrad. When someone recognized her, a woman with blue lips "came out of the numbness which affected us all and whispered in my ear - (we all spoke in whispers there): 'Can you describe this?' I said, 'I can!' Then something resembling a smile slipped over what had once been her face." ${ }^{12}$ Having survived and maintained her own lyric voice, she could speak for the fallen succinctly in the mode of elegy. Nadezhda Mandelstam noticed the same vocation to witness in Pasternak already in the 1930s: “...every time we met him he told us he was writing a prose work 'about us all."13 Unlike Akhmatova's, Pasternak's memorial after decades in the writing attained monumental scope, though the work seems uneasy about its own scale. As Zhivago's career follows Pasternak's own progression from poetry to prose (that is, the writing of this very novel), the narrative confesses its involvement in the Tolstoyan paradox fighting fire with fire - of countering the old, deluded heroics through a sweeping vision that may in time prove just as clumsy and oppressive. Zhivago ends the creative and poetic part of his solitude at Varykino and begins the final, futile phase of his career as a voluminous writer of prose by a vision of how the Tolstoyan "great men" and Napoleons of history have

${ }^{10}$ Pasternak, 418.

${ }^{11}$ Nadezhda Mandelstam, 251.

12 Anna Akhmatova, Poems of Anna Akhmatova, trans. Stanley Kunitz and Max Hayward (Boston: Little Brown and Company, 1973), 91.

${ }^{13}$ Nadezhda Mandelstam, 299. 
been replaced by fanatical revolutionaries. ${ }^{14}$ Pasternak's melancholy about how an inhuman age has reduced him to speaking in monumental terms does not make him the less like Virgil.

Nadezhda Mandelstam writes on the same scale but with less selfconsciousness about the form. Despite the real uncertainty of her position, especially while her husband's poems remain unpublished in Russia, her tones are more triumphant than Pasternak's, as well as sometimes starker. She confesses herself an optimist, like her husband. What she narrates, from the 1934 arrest up to the second arrest in 1937, is a struggle that inspired Richard Pevear to make the comparison to Homeric battle. ${ }^{15}$ The narrative begins with a famous leap in medias res: "After slapping Alexei Tolstoi in the face, $M$ [andelstam] immediately returned to Moscow." 16 What matters in her world, as in Homer's, is that the tale, the kleos, endure: "If nothing else is left, one must scream. Silence is the real crime against humanity."17 Yet she is already willing to declare victory, since the Stalinist battle was waged not just against perishable human resistance but against the Mind itself. Her husband's experience, like that of the fictional Zhivago, speaks for his generation, for Russia, and ultimately for the experience of man in history:

Russia once saved the Christian culture of Europe from the Tatars, and in the past fifty years, by taking the brunt on herself, she has saved Europe again - this time from rationalism and all the will to evil that goes with it. The sacrifice in human life was enormous. How can I believe it was all in vain? ${ }^{18}$

Russia's sacrificial role in history, as it inevitably recalls that of Israel, figures in the Judeo-Christian tradition of apocalypse, of which these memoirs are a chapter: " $M$ [andelstam] taught me to believe that history is a practical testing-ground for the ways of good and evil." ${ }^{19}$

${ }^{14}$ Pasternak, 378.

15 Richard Pevear, "On the Memiors of Nadezhda Mandelstam," Hudson Review 24, no. 3 (1971): 427-28.

\footnotetext{
${ }^{16}$ Nadezhda Mandelstam, 3.

17 Ibid, 43.

${ }^{18}$ Ibid, 329.

${ }^{19}$ Ibid, 328.
} 
Though Bakhtin does not center his larger history of culture on the case of a single writer, his theoretical overview shares many of the same assumptions as the other two and provides terms to interpret them. He, too, charts through history the triumphant emergence of the voices of resistance, which he identifies not in terms of lyric but of irony, humor, and polyphony - the constellation of qualities that constitutes the "novelistic." This honest, joking, subversive tendency has long been at war with the deadening hand of authority, centralization, and tradition, which in now influential essays from the 1940s Bakhtin labels the "epic." Like the other two, he sees cultural creativity as centrifugal, to be found not in the centers of power and cultural authority but on the margins, especially where languages and cultures intermingle: not the court, but the marketplace; not Athens, but the Hellenistic cities; not Rome, but Lucian's polyglot Samosata in Syria.

Confirmations of this centrifugal tendency can be noted in the careers of Yurii Zhivago and Osip Mandelstam. It is Zhivago's trip to the Urals, to Varykino, that calls forth the poems in the concluding poem cycle, just as in fact Osip Mandelstam's visit to Armenia ended five years of writer's block. In his wife's view his status as a perpetual wanderer was fundamental to his creativity, while his "antipode" Pasternak paid a steep artistic price for the privilege of staying in Moscow. Moscow in both works ends up seeming hostage to a hollow and tyrannical "now," and it is on the margins that one enters into another, more natural and human reality that also gives access to antiquity. In the Urals Zhivago runs into figures named Bacchus, Lupus, Faustus, Liberius; Mandelstam's Armenia is in contact with Italy and antiquity. Of Sevan Island Mandelstam observes, only half-humorously: "The entire island is Homerically strewn with yellowed bones - remnants of the local people's pious picnics." 20

While Bakhtin's resistance to state authority and its attempts to monopolize meaning is similar to that of the other two, though far more deeply encoded, his reaction to literary authority seems, at least on the surface, almost to be the opposite. Though trained as a classical philologist, Bakhtin resists classicism, traditionalism, and canon-building. Pasternak and the Mandelstams welcome classic writers as collaborators in their escape from the terrors of the current age. Even exile itself has its

${ }^{20}$ Mandelstam, 174. 
own venerable traditions. Where the exiled Pushkin invoked Ovid, Osip Mandelstam invokes Pushkin, as well as Dante, to figure his own wandering. Zhivago's second visit to Varykino brings him to "the dark forest of his life," 21 where wolves worthy of Inferno 1 appear on the horizon. Yet in Bakhtin's formulation, such invocations of literary authority must stand as part of the deadening "epic" mentality. Bakhtin is the only one of the three to work from the assumption that epic does in fact belong to princes and that the voices of resistance necessarily take other forms.

We have, then, a disagreement deeper than the generic differences of novel, memoir, and literary theory. Though all three tell parts of the same tale of how honest and subversive voices survive and prevail against the organs of oppression, Pasternak and Nadezhda Mandelstam create heroic memorials to the generation, the nation, and the race. Bakhtin might see these didactic monuments as built on the dead and rotten wood of "epic."

To sort out these disagreements we shall look now separately at Pasternak's fictional (auto)biography, Bakhtin's socio-poetic theory and its resistance to such "epic" projects, and finally Mrs. Mandelstam's synthesis of both modes within the matrix of her own memories.

Pasternak's debts specifically to literary epic go very deep, as we have argued..$^{22}$ Doctor Zhivago presents a proliferation of allegorical systems laid one upon another. As is evident from the concluding cycle of poems on Christ's Passion, Zhivago projects himself into the roles of Adam, Jesus, and Judas, even as he sees Lara in terms of Eve, Magdalene, and the Virgin Mary. The narrator recounts the poet's three days of descent into hell in a bout of fever; the final poem, "Garden of Gethsemane," ties itself back to the narrative by ending the cycle not with crucifixion or resurrection, but arrest, as is appropriate to the generation being described and to Zhivago himself when he writes at Varykino in anticipation of his own arrest. The use of a poet as an Everyman evokes Dante, as do the "dark forest" and wolves of Varykino. Zhivago's final inspiration, like Dante's, lies in the loss of his donna. Dante allusively brings Virgil with him, so that at another level Yurii and Lara play out the tragedy of Aeneas and Dido. Lara, like Dido, offers an interlude between an abandoned first wife, symbol of the old order, and a somewhat faceless second wife, symbol of the new.

\footnotetext{
${ }^{21}$ Pasternak, 369-70.

${ }^{22}$ See the introduction to this volume.
} 
Both Zhivago and Aeneas, denied the dignity of self-immolation, outlive the individuals and the social order dear to them and end their tales as distant, lifeless characters. These curiously passive protagonists make ideal witnesses to the larger mechanisms of a history that may be at war with personal meanings. Pasternak may end up siding more with Virgilian nostalgia than with Dante's sense of deliverance.

Pasternak's allusions evoke not only the Aeneid and the Divine Comedy, but also their authors' careers, which exemplify the tensions between poetry and authority in Rome and Florence. Both Dante and Virgil started as poets of shorter forms whom events (exile from Florence or the pressure of Augustus) forced to monumental statements. Like Pasternak, these poets saw their worlds turned upside down by civil strife and confronted an order that in some ways they found criminal or inhuman. All three managed to survive where others did not, as seems particularly apparent in the portrayals of Aeneas and Zhivago as regretful survivor-protagonists. Though Aeneas founds a new imperial order, while Zhivago is extruded, both experience an erosion of feeling and a descent into silence.

Concerning the relationship of epic and despotism, Pasternak's own career suggests that some versions of totalitarianism leave no stance for the artist but that of epic writer. Already in 1927 he announced the intention to turn to prose because "epic is what our time inspires."23 The bella scuola of precursors, especially Virgil and Dante, can be proudly invoked as a tradition of doubt and resistance. Princes may then have a role in the creation of monumental art - by virtue of just barely failing to crush its poets. The artists who survive the tyrant may be transformed by the experience from lyric poets into chroniclers of the national experience.

While exploiting the scope and didacticism of prose to make his case, Pasternak will not renounce the claims of the lyric poet, as becomes apparent by the end of the volume. The tale is, after all, that of a poet being silenced; the tragedy of Zhivago is that of the poet who dies before the man, who lives on to be a prolific writer of tracts. The numerous references to Tolstoy, especially in Zhivago's final apocalypse at Varykino, may recall the pitfalls of constructing large, didactic systems in honor of the small, the daily, and the plain. Proceeding without any introduction or annotation from the prose narrative to the cycle of poems printed at the end of Doctor

${ }^{23}$ Boris Pasternak, Sochineniya, vol. III (Ann Arbor: Ardis, 1961), 215-216. 
Zhivago, we may wonder what encompasses what: Are the poems a footnote to the main story, an addendum? Or is the prose narrative a prologue to and commentary on the poems, as Mrs. Mandelstam means her memoirs to be? The poems articulate a vision of the Christ-inspired history toward which Zhivago and Lara have struggled. Even the narrative of events at Varykino, the zenith of Zhivago's poetic productivity, begins to erode the boundaries between text and life: "Like the confusion of a first rough draft, the wearisome inactivity of the day was a necessary preparation for the night." ${ }^{24}$ Lara has a dissociative sense of their life in this interval: "... and now we bustle around like mad so as not to see that this isn't life, that it's a stage set, that it isn't real, that it's all 'pretend,' as children say, a child's game - just ridiculous." ${ }^{25}$ Her protest apparently inspires a reply in "Hamlet" with its conceit of life as a play, and with its ending, "To live life to the end is not a childish task." ${ }^{26}$ In giving insight into Zhivago's thoughts at Varykino, the poem's expansive allusions imply worlds of experience within which the preceding biography is a mere footnote: Zhivago casts himself as an actor, perhaps playing a Hamlet who himself plays Jesus. That the creator of Zhivago famously gave Russian voice to Shakespeare's prince may recall the decades of translation that marked the suppression of Pasternak's own lyric voice, for similar ventriloquism now proliferates in the "Hamlet" ode. Pasternak's biography can be taken as a matrix for, or perhaps just a footnote to, Zhivago's poem. The hierarchy of textual authority cannot be established. The narrative of Zhivago's life contains a copious survey of decades and events, but the lyric poems, especially as they modulate into the voice of Jesus, encompass eternities.

This irresolvable tension between poetry and prose, also to be found in the works of Osip and Nadezhda Mandelstam, in the case of Doctor Zhivago conforms to Bakhtin's view of the novel as the form that can contain other forms and set them into dialogue with one another. Just as the "novelistic" tendency made a crucial advance through the mixture of prose and poetry in Menippean satire, so Pasternak's prose narrative can be seen as providing a meta-form set around the poems to draw out the ideology so perfectly unvoiced in Zhivago's passionate sincerity. Yet in attaching Doctor Zhivago

\footnotetext{
${ }^{24}$ Pasternak, Doctor Zhivago, 366.

25 Ibid, 360-61.

${ }^{26} \mathrm{Ibid}, 433$.
} 
to the tradition of Virgil and Dante, Pasternak presumably becomes subject to Bakhtin's assault on "epic," inasmuch as such hybridization of prose and poetry should not serve the cause of classicism and concerted vision in the way that Doctor Zhivago manifestly does. Guy de Mallac speculates that Bakhtin would not find Pasternak's novel very "novelistic" since its speakers, many and various as they are, monophonically express a single set of opinions. ${ }^{27}$ Yet the contradictions in Pasternak's own reaction to Stalinism - reduced to monumentality notwithstanding himself - raise suspicions about the neutrality and consistency of Bakhtin's radical anticlassicism. Though he, unlike Pasternak and the Mandelstams, entirely concedes epic to the use of princes, his renunciation of the tradition may be more apparent than real.

Bakhtin, like the others, is a survivor of Stalinism. He spent three decades exiled from the capitals, mostly barred from publication and academic appointments. In those decades he produced nine long books, of which one, on Dostoevsky, was published in 1929, while the next, on Rabelais, appeared in 1965. Other manuscripts got lost or suppressed or ripped up for cigarette papers. Like the others he found his influential "voice" only after Stalin's death. What he wrote under Stalin in various ways compensates for the freedom and audience denied him.

For the understanding of the novel, these theories are a contribution of the first rank. We must also note that for students of epic Bakhtin represents a significant nuisance, since his genre theory, which is also a philosophy of history, radically simplifies and scapegoats the "epic" as the mouthpiece of the bad old days, the days of a monolithic, authoritarian, elitist culture. ${ }^{28} \mathrm{To}$ some degree, the daunting complexity of Bakhtin's analytical task compels him to use a straw man of one sort or another: With the "novelistic," as with other forms of irony, the interpreter who undertakes to chart the quicksilver movements of its deflation (mockery, subversion, parody, or "dialogizing") of its targets cannot afford to admit how much these targets themselves

27 Guy de Mallac, Boris Pasternak: His Life and Art (Norman: University of Oklahoma Press, 1981), 297.

${ }^{28}$ For a more extensive critique of Bakhtin's theories of epic and novel, see Chapter 1 of this volume. For a reading of the Odyssey in terms of "novelistic," see now John Peradotto, "The Social Control of Sexuality: Odyssean Dialogics," Arethusa 26 (1993): 173-82. 
already use the same ironies (i.e., have their own targets). Plato goes after Aristophanes, who was himself going after Euripides, who was going after Aeschylus, who was going after Homer, who was going after...? Rather than credit infinite chains of ironizing (or "novelizing") in all directions, Bakhtin invents an end to the regress by positing a literature without targets, without irony, without complexity: the monophonic "epic." As the end of the regress, that literature has to be Homer, who is earlier than any other European text. Homer is the only "epic" writer cited.

By making "epic" the straw man, Bakhtin has popularized and reinforced long-discredited simplifications. Uses of epic rarely, if ever, conform to Bakhtin's description of a monolithic expression of nationalist orthodoxies and, indeed, are usually quite opposite in tendency. Bakhtin excludes the qualities of melancholy and resistance that Pasternak and the Mandelstams evoke from the tradition, as well as the polyphonies of the uniquely rich intertextuality of the epic tradition. The bard's complicated textual "dialogizing" of predecessors (Dante of Virgil, Virgil of Homer) does not so much make him a cultural imperialist as prevent him from serving the ideologies of his own day in any simple way. As the Mandelstams remind us, Dante is the literature of the prisoners more than of the jailers. Ullrich Langer's category of "boring epic" fits Bakhtin's description and is a reality of literary production, but is not what usually constitutes the canon. The mainstays of that canon - the Iliad and Odyssey, the Aeneid, the Divine Comedy - are in their various ages striking experiments in "novelistic" tendency. Canonization, translation, and veneration may have dulled their rough edges and gilded them with oppressive "epic" associations, but these texts all continue to move readers by something other than the "official" tones retrospectively imposed on them.

Bakhtin does parallel Pasternak's and the Mandelstams' view of the relationship of the center and the margins in cultural history. The center (read: "Moscow" or, more specifically, "the Kremlin") is where culture dies, to be redeemed only by resistance at the margins by the irreverent culture of the "people." All these writers would agree on the evils of enforced centralization and cultural homogenization; all give priority to the play of individual voices. Bakhtin further, and largely in opposition to the others, makes the "epic" the literature of the court and has the "novelistic" express the folk laughter of the marketplace. However, his attempt to flesh out this paradigm with names and places succeeds poorly. The only "epic" 
poet cited, Homer, derived from and became the basis of a widespread popular (indeed, oral) culture. The Homeric poems came from the margins of the Greek-speaking world, Ionia - perhaps at the remove necessary to see Panhellenic culture for the first time as a unity. And "Homer" was the spokesman of a "nation" that existed only in the imagination and for which he does not have a name. Epics do regularly, as Bakhtin observes, express the longing for a cultural center, but it is regularly the lack of same that inspires colonials, exiles, expatriates, and political outsiders to give monumental utterance to those hopes, as we discussed at the outset. If one takes epics as a subspecies of the "novelistic" (as Bakhtin himself does in other essays), his theories of cultural generativity capably account for their origins. If epics are often closer to the dissident voices of the marketplace than Bakhtin quite admits, the populist credentials of the "novelistic" are often questionable. The "novelistic" promotion of popular forms (like the dialogue) into literature regularly served for the amusement of the intelligentsia in the capitals: Plato (Bakhtin mentions only Socrates, who wrote nothing), the Greek novel, Petronius (a courtier of Nero), Rabelais. Writers such as Plato and perhaps Rabelais ${ }^{29}$ may, ironically, evoke the life of the streets in support of a new set of elitist values. The popular form of the dialogue became the charter of the institutionalized exclusivity of the Academy. Bakhtin adroitly counters Marxism by finding in the historical circumstances of cultural production a principle to overthrow Marxist orthodoxy, but overlooks the even larger irony that it has often been the established elites (including, as Mrs. Mandelstam notes, Stalin's Union of Writers) that have the leisure to savor and memorialize popular culture. It may be the outsiders and have-nots who need the rallying cry of heroic literature.

Since Bakhtin's own histories, as befits his time, are encoded and polyphonic, it may be a disservice to take him too literally. He may be better served by being read, like Pasternak and Mrs. Mandelstam, in terms of the larger visionary project of constructing a history of voice. Where the other two use the 1920s and 1930s as a lens on preceding centuries, Bakhtin restricts himself to those earlier centuries as a way of talking about an undiscussable present. Though his description of the stultifying

${ }^{29}$ See Richard M. Berrong, Rabelais and Bakhtin: Popular Culture in Gargantua and Pantagruel (Lincoln and London: University of Nebraska Press, 1986). 
uniformity and authoritarianism of "epic" describes the tradition oddly, it applies closely to the socialist realist novel. ${ }^{30}$ The deadening authority of an absolutely valorized heroic "then" may be his way of describing the tyranny of Stalinism's heroic "now." Always alerting us to the telling loopholes in any ideological system, Bakhtin himself provides an intriguing loophole concerning this very issue: "It is possible, of course, to conceive even 'my time' as heroic, epic time, when it is seen as historically significant; one can distance it, look at it from afar (not from one's own vantage point but from some point in the future)...." ${ }^{31}$ He goes on to describe latter-day "epic," again without examples, in ways that capture the output of the Union of Writers: The later versions of "epic" "...transfer to these [contemporary] events the time-and-value contour of the past, thus attaching them to the world of fathers, of beginnings and peak times - canonizing these events, as it were, while they are still current." 32 Soviet society, with its cults of Lenin and Stalin, had constituted itself as the epoch of the fathers, and its stategenerated literature depicted a world (again, Bakhtin is here describing "epic") "...that is inaccessible to personal experience and does not permit an individual, personal point of view or evaluation." ${ }^{33}$ What he describes comes not from a traditional society like Archaic Greece but a police state founded on rigid orthodoxy: "The epic world is an utterly finished thing... it is impossible to change, to re-think, to re-evaluate anything in it. It is completed, conclusive and immutable, as a fact, an idea, a value." ${ }^{34}$ Even Bakhtin's image of the monolith as a symbol of the "epic" continues to have currency among critics of the regime. Mrs. Mandelstam, writing in the 1960s, and Andrei Sinyavsky both use the Egyptian pyramid as a symbol of the vast, inhuman structure of the Soviet state. ${ }^{35}$

30 Katerina Clark and Michael Holquist, Mikhail Bakhtin (Cambridge, Mass. and London: Harvard University Press, 1984), 273.

31 Mikhail Bakhtin, The Dialogic Imagination, ed. Michael Holquist, trans. Caryl Emerson and Michael Holquist (Austin, University of Texas Press, 1981), 14.

32 lbid, 14-15.

${ }^{33}$ Ibid, 16.

${ }^{34}$ Ibid, 17.

${ }^{35}$ Nadezhda Mandelstam, 256; Andrei Sinyavsky, Soviet Civilization, trans. Joanne Turnbull and Nikolai Formozov (New York: Arcade Publishing, 1990), 267. 
It is a long way from the Iliad to socialist realism, but Bakhtin facilitates the double reference by leaving the category of the "epic" empty, credited as a generative principle in human culture, but without names attached. In the first, and very dense, twenty-one pages of the essay "Epic and Novel," the form is described in detail without a single "epic" writer being named, though Homer is implied. The essay shifts at that point to the ancient precursors of the novel and in the next paragraph mentions Sophron, Ion of Chios, Critias, Lucilius, Horace, Persius, Juvenal, Petronius, Menippus, and Lucian. Bakhtin is scarcely sparing the general reader the burden of his erudition. In the stark asymmetry between all the famous bards who are not mentioned and the numerous obscure prose writers who are, the unexemplified category of "epic" becomes all the more problematic. The shadowy, eccentrically described "Homer" can be nothing more than a place holder in Bakhtin's system, and the modern "Homers" who canonize the present have been left to be deduced, even as Osip Mandelstam could leave it to the reader to find the unnamed Stalin in the shadow of Farinata and Ulysses. Stalin trained readers well for allegorizing classic texts into "missiles for capturing the future." For "epic," then, read "socialist realism." The loopholes in Bakhtin's description suggest that what defines "epic" is not when it was written (for it can be modern) nor the era that it describes (for it can canonize the present) but rather the ideological rigidity of refusing to allow "then" and "now" to comment on (or "dialogize") one another and claiming one age as the absolute standard of all others.

Bakhtin describes in broad, essentially allegorical terms that great war in history between truth and the lie, between mind and mechanical, deadening force. This is a heroic tale in its own right, and Bakhtin's rhetoric belies his sympathy for the writers who have jovially turned aside from "kings and battles." To excerpt from the 1941 essay "Epic and Novel": "The novel has become the leading hero in the drama of literary development in our time precisely because it best of all reflects the tendencies of a new world still in the making...." ${ }^{36}$ (Bakhtin 1981, 7). "[The novel] fights for its own hegemony in literature; wherever it triumphs, the other older genres go into decline" (4), a process later described as "a lengthy battle for the novelization of the other genres" (39). ${ }^{37}$ The novel is, in a word,

\footnotetext{
${ }^{36}$ Bakhtin, 7.

${ }^{37}$ Ibid, 4, 39.
} 
revolutionary: "In the process of becoming the dominant genre, the novel sparks the renovation of all other genres, it infects them with its spirit of process and inconclusiveness. It draws them ineluctably into its orbit precisely because this orbit coincides with the basic direction of literature as a whole" (7). ${ }^{38}$ Genres of the world unite! You have nothing to lose but your monophony! The triumph of the "novelistic" has all of the redemptiveness and historical inevitability being claimed in these years for its demon twin, Marxism. Bakhtin ends up describing the overthrow of "epic" as an epic struggle.

Though the "novelistic" is the enemy of the nationalism that propels the "epic," Bakhtin's larger history leads to Russia with a sure aim. The genres that Bakhtin esteems in antiquity - the ironizing, personalistic, seriocomic prose narratives - are the ancestors of forms that have distinguished Russian letters. Bakhtin the iconoclast and anti-classicist may be, in nationalist terms, a pious antiquarian and patriot who gives Russian letters a connection with antiquity that, for want of a Renaissance and Enlightenment, it would seem to lack. Bakhtin creates a canon stretching from the holy fool Socrates to Petronius to Rabelais and onward to Gogol and Dostoevsky. As universal as the "novelistic" tendency is, this is a prehistory that finds its culmination nowhere so clearly as in Russia itself. The irony is familiar: The enemy of theory builds his own theory; the canon-basher substitutes an alternative canon. Though the virtue of the "novelistic" is its focus on the open-ended present, Bakhtin, like any good classicist, finds its essence in its origins. The canon is dead! Long live the canon! Bakhtin has paid the epic tradition the compliment of replacing it with one that functions in much the same way, and one built of even bigger texts, the "loose baggy monsters" most esteemed in Russia.

To sum up, on the topic of epic itself, the extremes of Stalinism drove Bakhtin and Pasternak to what are on the surface opposite answers. Bakhtin links epic with authoritarianism and dances on its grave. Pasternak recalls and revives another tradition wherein epic springs from the resistance to princes and tyrants. In one particular, they show a common inclination: to

38 Ibid, 7. Berrong notes how popular culture "struggles against," "storms," and even "destroys" official culture in Bakhtin (Rabelais and His World), a study of Rabelais written during the 1930s and 1940s. Richard M. Berrong, Rabeleis and Bakhtin: Popular Culture in Gargantua and Pantagruel (Lincoln and London: University of Nebraska Press, 1986), 11. 
give Russian letters a prehistory that leaves them less hostage to the politics of this century. This shared sense of history follows along Christian lines (as remains unstated in Bakhtin's essays) and stands in opposition to the mechanistic and the authoritarian. Bakhtin assembles an anti-canon of iconoclasts, but one strangely like the tradition that it replaces and heroic in its own terms. Pasternak, working in the shadow of Virgil and Dante, seems more aware of the Tolstoyan trap of replacing one kind of heroics with another. Both demonstrate how the society of the future in abolishing the past had given it a ferocious new glamour. Try to make the New Man and he will inevitably long to be the New Adam.

Nadezhda Mandelstam, like her husband, sides with the classicists and invokes "Europe" as the codeword for the humanistic values outlawed by Stalinism. Like Bakhtin she sees cultural history as a logomachy, a clash of discourses, that can be traced by moments of ironic dissonance. Her personal and immediate goal is to assert her true telling of events against the proliferation of self-serving legends, bureaucratic obfuscations and deceits, and naive misperceptions that inevitably surround the suffering and death of a famous poet. Her text is, properly speaking, a polemic, a part of the continuing conflict, and therein lies its immediacy. Her own struggle as a writer exemplifies and comments on the conflict of discourses in Soviet society as the official, centralizing line of the state assaults, but fails to destroy, the honest and irreverent voices of individuals. The depicted struggles of the polyphonic resistance to a dead and deadening unanimity parallel from life the emergence of "the novelistic" into literature.

As an example of her technique of letting language be history, we may take the chapter entitled "The Accomplice," which concerns an "admirer" of Mandelstam's verse, Alexander Fadeyev, a socialist-realist novelist and functionary of the Union of Writers. Fadeyev had both the discrimination to be moved by the verse and the decayed decency to offer praise, consolation, and insincere promises of help. As is observed time and again in the memoirs, the only art left to the complicit intelligentsia is to re-enact eternally the Judas-kiss:

Less than a year later, during a party in Lavrushinski Street to celebrate the award of the first Government decorations to be given to writers, Fadeyev learned about the death of M[andelstam] and drank to his memory with the words "We have done away with a great poet." Translated 
into Soviet idiom, this meant: "You can't make an omelet without breaking eggs." 39

As would Bakhtin, Mrs. Mandelstam locates the meaning of Fadeyev's utterance in its context, which encompasses a play of discourses, spoken and unspoken. Fadeyev's official and ceremonious tribute translates the homely and unspoken idiom of the maxim. At yet a further level - and here she parts company with Bakhtin - this irreverent fragment of folk wisdom is itself hideously corrupted by public life, a symptom of what outrages her most: the people's passive acceptance of the terror as if (unless one's own family is affected) it mattered no more than omelets and eggs. The great hypocrite Fadeyev implicates the small, unresisting hypocrites (and she excludes no one, not even her husband or herself) who allow the charade to proceed to its lethal outcome. She sees no redemption in the well-policed marketplace. Dismissing both Fadeyev and his collaborators to their native oblivion ("But it scarcely matters who actually signed the sentence..."), she turns the mirror on the audience: "And is it conceivable that people will not learn from our example?"40

Mrs. Mandelstam does, like Bakhtin, credit the languages of the people and of daily life (where her husband chose to see himself, "herded with the herd") as the source of truth and moral value. But her reading of polyphony in the society is nearly opposite to Bakhtin's. Polyphony does, as he claims, result from the resistance to authoritarianism, enforced uniformity, and soulless elitism. Yet her memoirs depict this play of voices as pathological, not redemptive: "My name is legion." The attempts to impose the lie or to accept it with enforced Soviet smiles unleash legions of competing discourses: from the ungrounded, comforting, constantly mutating speculations about why acquaintances got arrested ("What for?") to the final monster in the narrative, Tiufiakov, who visits the widow every day with new inventions about her husband's fate - shot, beaten to death, still alive, run off with another woman. Interrogation rooms are identifiable because they have too many doors. Where Bakhtin locates creativity in the circumventing and subverting of authority, Mrs. Mandelstam finds inventiveness mostly in the slips and small emotional self-indulgences (the

\footnotetext{
${ }^{39}$ Nadezhda Mandelstam, 355.

${ }^{40} \mathrm{Ibid}, 356$.
} 
Judas role) that characterize the universal complicity. The poet's role, and Mrs. Mandelstam's in speaking for her husband, is to assert the unitary truth beneath the proliferation of voices. So much is apparent at the first arrest in 1934: “What for?' Akhmatova would cry indignantly whenever, infected by the prevailing climate, anyone of our circle asked this question. 'What do you mean, what for? It's time you understood that people are arrested for nothing!"'41 Though an acute observer of how polyphony is generated by the play of discourses in the culture, Mrs. Mandelstam's aim is to assert the unity of truth. Her moral absolutism is unconcealed.

Though she permits herself scores of obiter dicta on literary, historical, moral, and philosophical topics, the force of her argument lies in the gallery of characters that crossed her path between 1934 and 1938, usually set against the false hopes of the 1920s and, sub specie aeternitatis, the perspective of the 1960s when, as individuals and groups, they are mostly exterminated, executioners no less than victims. This extraordinary prosopography of individuals set against the absolute claims of death recalls in its scope and format the strings of cameos in the Iliad and the Divine Comedy. In all three, individuals are given a brief moment on the stage to move under their own energy to the characterizing posture (of dying in Homer, of death in Dante) where they are captured for eternity. Lives distill themselves into a gesture, a word, a deluded hope: Years later, his duplicity revealed, the drunken Fadeyev whispers to the widow in a Moscow elevator the name of her husband's executioner - as if she cared, or would believe him, or respect him even if she did. Cheka interrogators give their victims hard candy - as if those victims could savor being compelled to pretend that there was some human basis to the interchange. The larger argument against historical determinism is not made on the level of theory (its own terms, after all), but in vignettes that open from Marx and end with Dante. Individuals are introduced categorically by the epithets of the new society: "a proletarian," "a non-Party Bolshevik" (which earlier would have been "a fellow traveler"), "a Red professor," an "officer of the Union of Writers." But it is always by free choice that they make the gratuitous and eccentric gestures that fix them for posterity. Even the despised Stalinist sister-in-law Tania finds her memorial not in party ideology (which keeps changing on her) but in telling moments of practice: stealing and selling her comatose

${ }^{41}$ Ibid, 11. 
stepdaughter's clothing on the day before she dies; uncontrollably turning aside when the unworthy successor Khrushchev drives past on a Leningrad street. Polemical as are her intentions, Mrs. Mandelstam, like Dante, does not overtly sit in judgment so much as catalogue individuals who have gravitated to their own natural positions. She establishes her own credibility, as well as enlivening the ghastly tale with surprise, by spotting vestiges of decency in the persecutors. But these humanizing touches are, as in the Inferno, the pinions that affix the damned to their torment. Even the most despicable are characterized not by naked cruelty so much as by the small hypocrisies - the hard candy, the amiable handshake, the praise for the poetry, the consoling word - that acknowledge the victim's humanity and betray the sinner's own conscious choice in proceeding. ${ }^{42}$ As in the Inferno, it is the humanity and recognizability of the faces that render the vision horrible rather than merely grotesque.

In the struggle over the continuing existence of Mind, the two Josephs, Stalin and Mandelstam, are cast as opponents and antitheses. Yet Mrs. Mandelstam takes care not to counter the Stalinist cult of personality with a comparably false hagiography of her husband. Indeed, she directly debunks the proliferations of legends about martyred poets that come to overshadow their poetry. Her husband remains a shadowy presence, and she does not aggrandize her own participation as anything beyond the future witness. ${ }^{43}$ As in the narrative of Doctor Zhivago, her prose contains numerous gestures of submission to the poetry. Though her textual authority rests in firsthand experience, she sometimes effaces herself from participant to eavesdropper: "M[andelstam] once asked me (or himself, rather) what it was that made someone a member of the intelligentsia." ${ }^{44} \mathrm{Her}$ own memory in places is shaped by later reading of his texts, which contain insights that he would not share with her lest she mock him. But then he himself rigorously subjected his own life to the principles articulated in his work. The effect of having Osip Emilevich and Nadezhda Yakovlevna almost disappear from the scenes of their own lives is to keep them from

${ }^{42}$ As Mrs. Mandelstam summarizes the matter: "Probably no other regime ever went in for such niceties in the art of bureaucratic control - apart from all its other qualities, it was distinguished by unparalleled hypocrisy." Ibid, 353.

43 lbid, 333.

${ }^{44}$ Ibid, 222. 
overshadowing the hero of the tale, the inextinguishable witnessing voice. Mrs. Mandelstam does let victory be proclaimed in the struggle, but only a poet is worthy to make the proclamation:

But poetry is a law to itself: it is impossible to bury it alive and even a powerful propaganda machinery such as ours cannot prevent it from living on. "I am easy in my mind now," Akhmatova said to me in the sixties. "We have seen how durable poetry is." 45

In being very nearly one of the missing persons in her own life - a curious absence at the core of what could be autobiography - Mrs. Mandelstam achieves some of the qualities of the omniscient observer and anonymous bard.

Her account is integrated at every level by an ethic of sacrifice that purges the reminiscences of narcissism. As was noted above, Russia itself has in her view been martyred for the cause of truth by living to the fullest the lies of rationalism. Poetry is validated as prophecy by the sufferings of the poet, the one figure most completely exempt from material advantage in a materialist culture. For the poet's wife, marriage becomes the sacrifice of all domestic rituals and comforts. In turn the widow becomes, in her husband's place, Stalin's adversary and bearer of the final victory. The order to "isolate and preserve" gave the poet three more years of life after 1934; the widow is given the injunction, we might say, to "preserve and proclaim."

Mrs. Mandelstam's polemical stance and self-confessed optimism set her apart from the traditional sentimentality of the widow's role. At Zhivago's bier, Lara at last finds independent voice in a lament that echoes images and values of Zhivago's poetry. Her emotionality was "like the choruses and monologues of ancient tragedies, like the language of poetry or music." ${ }^{46}$ Her lament recalls that of Igor's wife Euphrosinia from the walls of Putivl in the Lay of Igor's Campaign, as well as that of the Virgin Mary over her son. The funereal end of Pasternak's narrative also recalls the end of the Iliad, where Andromache, Hecuba, and Helen greet Hector's body as it is returned to Troy. Rather oppositely Mrs. Mandelstam uses tradition as a check on sentimental indulgences like suicide or survivor's guilt or even gestures of humility. She ends the account of the couple's dialogue on suicide

\footnotetext{
45 Pasternak, Doctor Zhivago, 417.

${ }^{46}$ Nadezhda Mandelstam, 57.
} 
by juxtaposing statements from the great Russian writers Mandelstam and Avvakum:

When M[andelstam] had gone and I was left alone, I was sustained by the memory of his words "Why do you think you ought to be happy?" and by the passage in the "Life" of the Archpriest Avvakum when his exhausted wife asks him: "How much further must we go?" and he replies: "Until the very grave, woman." Whereupon she gets to her feet and walks on. ${ }^{47}$

Part of the pathos of her position, which she need do nothing to amplify, is that she was never given the widow's due, the lament at the funeral. Her husband vanished, and she was given no body to tend but that of the poetry, which requires of her perseverance rather than deep emotion. In place of a conclusion the second volume of memoirs ends with an unsent letter to her husband from the end of 1938, approximately the time of his death. ${ }^{48}$ But, of course, she does not want a conclusion. She is not finished yet.

It is the unsentimental Homer who best anticipates the heroism of her partisanship. That best of wives, Andromache, also finds independent voice at her husband's death. She too confronts the ritual anomaly of being deprived of the corpse as Achilles abuses it. The atrocities of inhuman force leave both women with no ritual and public role, though Andromache is to have it later at Hector's funeral. She is reduced to the simple gesture of burning the clothing that she has prepared for her husband's return. The terms in which she does so are linguistically charged, as she proclaims that this sacrifice will be a kleos for him (Iliad 22.514). Kleos, "fame" or "honor," is the motivating word in the epic and not used often or casually. It is what warriors die for and what bards provide. Had Hector won, he would have had that kleos. Achilles has claimed it along with the fallen body that properly belongs to the widow. Yet to a curious degree, the victory in this opposition belongs to Andromache more than Achilles. As gods and men agree, his crazed mutilation of the corpse taints the moment of triumph and vitiates his own kleos. At a moment when he could claim the supreme meaning that warrior culture has to offer and shape his own immortal

47 Nadezhda Mandelstam, Hope Abandoned, trans. Max Hayward (New York: Athenaeum, 1974), 619-21.

48 Joseph Brodsky, "Nadezhda Mandelstam (1899-1980): An Obituary," in Less Than One: Selected Essays, 145-56 (New York: Farrar, Straus, Giroux, 1986), 154. 
memory, he hurtles from the scene like a maniac, dragging the corpse. In his place, it is the widow who is given the privilege of concluding the climax of the work, fixing its meaning, and, in her own terms, prevailing over the self-destructive adversary, who in time, in the great scene with Priam, will accede to her values. In Homer's epic, the victims get the last word.

In similarly deprived and ritually anomalous circumstances, Mrs. Mandelstam claims no role for herself but to purvey kleos. Yet this kleos is more potent than mere "memory" or setting the documentary record straight. It is a role in the war. Stalin, like Achilles, is the self-cancelling monster of force who has compelled the hero's wife to take up the bard's own role. He has made her not just a widow, but something more. As Joseph Brodsky observed at her death, "She was a widow to culture...." Her impact may lie in the fact that "the status of the modern world vis-à-vis civilization also can be defined as widowhood." 49

Stalin drove her, like Pasternak and Bakhtin, to a scale of prophecy that none of them might have anticipated in the 1920s. As Brodsky noted, "... she became what she became not because of what took place in Russia in this century but rather in spite of it." 50 That "in spite of" provides one answer to our initial question about the relation of heroic literature to princes. As Anna Akhmatova demonstrated, the step to monumental form was not inevitable, for lyric poets could, if they survived, still recall the terror in lyric poems. But when it happened, this step to a broader canvas and a millennial vision clearly reflected its times. Pasternak said as much in 1927 in declaring that "epic is what our age inspires." The ideological tyranny that instilled Bakhtin's remarkable insight into the voices that can subvert orthodoxy not only called forth description on the broadest historical scale but also kept him from calling the oppressive "epic" forces by name. Mrs. Mandelstam's memoirs make the linkage of epoch and epic fully transparent, for the atrocities of the age provoked her to realize the effects of heroic literature without the need of fiction in a way that may recapture the earliest workings of imperishable kleos.

${ }^{49}$ Ibid, 154-55.

${ }^{50}$ On Mrs. Mandelstam's rhetorical position in the text and representation of her role as wife, see the important analysis of Charles Isenberg, "The Rhetoric of Nadezhda Mandelstam's Hope Against Hope," in Autobiographical Statements in Twentieth Century Russian Literature, ed. Jane Gary Harris (Princeton, N.J.: Princeton University Press, 1990), 192-203. 